\title{
TOWARDS A NEW CANON: ENSAYO SOBRE LA LITERATURA INGLESA (1881) AND THE RECEPTION OF ENGLISH LITERATURE IN SPAIN IN THE NINETEENTH CENTURY
}

\author{
(1) (1) (8) \\ Sara Medina CAlzada ${ }^{1}$ \\ Universidad de Valladolid
}

\begin{abstract}
This paper examines Joaquín Henrich y Girona's Ensayo sobre la literatura inglesa (1881), the first complete history of English literature written in Spanish. Published at a time when the knowledge and interest in English writers was increasing in Spain, Henrich's work is part of the process of formation of a new and wider English canon that was taking place in the last decades of the nineteenth century.
\end{abstract}

Key words

Literary historiography, canon, reception of English literature in Spain, nineteenth century.

\section{Resumen}

Este artículo analiza Ensayo sobre la literatura inglesa, obra de Joaquín Henrich y Girona publicada en 1881 que puede considerarse la primera historia completa de la literatura inglesa escrita en español. Su publicación se enmarca en una fase de la recepción de la literatura inglesa en España en la que crece el conocimiento y el interés por esta literatura y, como consecuencia, se configura un nuevo canon literario inglés.

Palabras clave

Historiografía literaria, canon, recepción de literatura inglesa en España, siglo XIX.

\section{INTRODUCTION}

In mid-nineteenth-century Spain, literary history emerged as a new discipline and gradually replaced the traditional study of poetics and rhetoric. This change in the approach of the study of literature resulted in the elaboration of literary histories of Spanish and foreign literatures. Regarding English literature, the first Spanish work that explored its complete evolution from its origins to contemporary times was Joaquín Henrich y Girona's Ensayo sobre la literatura inglesa, which was published in Barcelona in 1881. The nephew of the wealthy banker and entrepreneur Manuel Girona, Joaquín Henrich belonged to one of the most distinguished bourgeois families in Catalonia ${ }^{2}$. He was involved in a series of business connected with the mining industry and railway construction. He collaborated with Juan Manuel Casademunt in the writing of the operetta Guerra alegre in 1890 and he published La reforma arancelaria, a work on trade and industry, in 1905. His brother Manuel Henrich owned the press Henrich y Compañía, which due to its technically avant-garde equipment and its eight hundred employees has been considered the most important press in Spain at the end of the nineteenth century (Botrel, 1993: 241; Llanas, 2004: 239). Henrich y Compañía

\footnotetext{
1 Universidad de Valladolid. Correo: smedina@fyl.uva.es. Recibido: 31-03-2014. Aceptado: 6-11-2014

2 For a detailed genealogy of the Girona family, see Cabana i Vancells (2002: 13). Joaquín Henrich y Girona was the son of Pablo Henrich and Esperanza Girona; his brother, Manuel Henrich y Girona, was a leading printer who became the major of Barcelona in 1893.
} 
was the successor of the press called Sucesores de Ramírez y Compañía (Llanas, 2004: 237), which printed Ensayo sobre la literatura inglesa. This work has been absolutely ignored in the study of literary historiography and has not been considered in the analysis of the presence and diffusion of English writers in Spain either, even though it can be regarded as the first complete history of English literature written in Spanish. Therefore, the purpose of this paper is to examine Henrich's work in relation to the reception of English literature in Spain in the nineteenth century. The focus will be placed on the selection of authors carried out by Henrich and its correspondence with the English canon that was being formed in Spain at that time.

\section{ENSAYO SOBRE LA LITERATURA INGLESA: SOME GENERAL ASPECTS}

Ensayo sobre la literatura inglesa is a one-volume overview of the history of English literature from the Anglo-Saxon period to the Victorian era. The work begins with a brief account of the formation and evolution of the English language in the Middle Ages, which is followed by a chronological relation of the lives and works of those whom Henrich considers the most important English authors: Chaucer, Spencer, Jonson, Shakespeare, Milton, Dryden, Swift, Pope, Scott, Byron, Dickens, etc. Following the Johnsonian tradition, special emphasis is placed on biographical data. The factual information on the writers and the critical analysis of some of their works are combined with the author's comments and views on particular periods, writers and literary pieces. Henrich's value judgments include both praising and condemnatory remarks. For example, he denies Defoe's talents as a novelist in the following terms:

Aunque Defoe es el introductor de la novela, no se le puede considerar como uno de los buenos escritores de este género literario. No hay en ninguna de las obras de Defoe, lo que caracteriza verdaderamente la novela (Henrich, 1881: 179).

On the contrary, he expresses his warm admiration for writers such as Shakespeare, Byron and Milton. For instance, he concludes his analysis of Paradise Lost by stating:

El primer libro de El paraíso perdido, es quizás la más grande y perfecta composición poética que se ha escrito, y el cuarto el más sublime y de imaginación más rica. Aunque estos son los dos principales libros del poema, hay, en los demás, pasajes que no les ceden en nada a los mejores de aquellos. Es un río de elocuencia que no se desvía nunca (Henrich, 1881: 139-140).

Nevertheless, it is difficult to discern whether Henrich expresses his own opinion or he simply reproduces his sources' views on the matter. Compare the following excerpt 
from George L. Craik's A Manual of English Literature (1862) with Henrich's judgement on Paradise Lost:

The First Book of that poem is probably the most splendid and perfect of human compositions -the one, that is to say, which unites these two qualities in the highest degree; and the Fourth is as unsurpassed for grace and luxuriance as that is for magnificence of imagination. And, though these are perhaps the two greatest books in the poem, taken each as a whole, there are passages in every one of the other books equal or almost equal to the finest in these. And worthy of the thoughts that breathe are the words that burn. A tide of gorgeous eloquence rolls on from beginning to end, like a river of molten gold (Craik, 1862: 318).

Ensayo sobre la literatura inglesa is preceded by a very short foreword in which the author briefly expounds his purpose when composing and publishing it:

Este trabajo fue hecho con objeto de familiarizarme en el estudio de la literatura inglesa. No existiendo ninguna obra de este género en español, me he decidido a publicar estos apuntes, sin embargo de conocer su escasísimo valor, creyendo que podrán ser de alguna utilidad a las personas que deseen conocer la lengua inglesa. Abrigo la esperanza de que plumas más autorizadas que la mía, se ocuparán en completarlos y desarrollarlos, y con ello darán mejor idea de la que yo pueda dar de una literatura interesante y variada (Henrich, 1881: 4).

He explains that he wrote these "notes" so as to become acquainted with English literature and that, despite their "little value", he decided to publish them because there was no other study of this type written in Spanish. Moreover, he indicates that his work was aimed at those who wanted to learn the English language. He does not refer to those who wanted to study English literature, but it should be borne in mind that literature usually represented both the purpose and the means of learning a foreign language in the nineteenth century. In any case, Henrich's Ensayo was not intended as a theoretical dissertation aimed at experts in literature, but as a guide for beginners. In fact, the text could have been used as a teaching manual in secondary schools in the late nineteenth century. Copies of this book are nowadays kept in the libraries of at least five Spanish high schools ${ }^{3}$. All these copies present the stamp of the book depository of the Ministerio de Fomento in the title page. In addition, the annual report of the Instituto provincial de Huelva for the academic year 1884-1885 records that Henrich's work was donated by the above-mentioned ministry (Instituto provincial, 1886: xxxiv), which suggests that the book might have been distributed in secondary educational institutions in the 1880 s.

3 Copies of Ensayo sobre la literatura inglesa are kept in the libraries of the IES Jorge Manrique (Palencia), IES Padre Suárez (Granada), IES Goya (Zaragoza), IES Mariano Quintanilla (Segovia) and IES Cardenal Cisneros (Madrid). Since many high schools have not catalogued their collections, there can be more copies in other educational institutions. 


\section{LITERARY HISTORIOGRAPHY AND HENRICH'S SOURCES}

Ensayo sobre la literatura inglesa can be considered the first complete history of English literature written in Spanish. As seen above, Henrich implicitly asserts so in the foreword by claiming that no one had ever published a work like his Ensayo in Spain (1881: 4). His boasts were fair because little had been written about English literature in Spanish from a historical approach. The first attempt to compose a history of English literature was Antonio Alcalá Galiano's Historia de la literatura española, francesa, inglesa e italiana en el siglo XVIII (1845), which collected a series of lectures that he had given in the Ateneo of Madrid. Alcalá Galiano deals with English literature in lectures IV, VII, XII, XIII, XIX, XX, and XXIII, but he focuses on eighteenth-century authors. The second approach to the history of English literature was Chateaubriand's Essai sur la littérature anglaise (1836), which was translated into Spanish by Francisco Madina-Veytia and included in the five-volume collection of Chateaubriand's works published in Madrid between 1852 and 1858. It also appeared as a separate book in 1857 under the title Ensayo sobre la literatura inglesa. It is uncertain whether it was a mere coincidence that Henrich would choose the very same title for his work twenty-four years later. He may have known Chateaubriand's essay, either in the French original or in translation, but he did not refer to it as one of his sources. In fact, the title and the subject matter seem to be the only similarities between the two homonymous works. Finally, also in 1857, Henry Mac-Veigh's The British Class Book o Lecciones de literatura inglesa was published. In spite of the title, it was not intended as a course on English literature, but as a manual for the teaching of English to Spanish speakers. It is an anthology of English texts with glossaries containing the Spanish translation of certain words appearing in the texts. Furthermore, it is preceded by a basic grammar of the English language and some rules regarding pronunciation.

Due to the scarcity of materials on the history of English literature available in Spanish, it is not surprising that Henrich would resort to foreign sources for the elaboration of his work. He acknowledges the following thirteen sources, which include English, French and German authors: Nicholas Rowe's The Works of Mr. William Shakespear (1709), Thomas Warton's History of English Poetry (1774-1781), Edmond Malone's The Plays and Poems of William Shakespeare (1790), Johann Wolfgang von Goethe's Wilhelm Meisters Lehrjahre (1795-1796), Joseph Ritson's Bibliographia poetica (1802), August Wilhelm Schlegel's Vorlesungen über dramatische Kunst und Literatur (1809-1811), François Guizot's CEuvres complètes de Shakspeare (1821), Henry Hallam's Introduction to the Literature of Europe in the Fifteenth, Sixteenth, and Seventeenth Centuries (1837-1839), Thomas Babington Macaulay's Critical and Historical Essays (1843), Howard Staunton's The Works of Shakespeare (1858-1860), George Lillie Craik's A Manual of English Literature 
(1862), Hippolyte Taine's Histoire de la littérature anglaise (1863-1864), and Paul de SaintVictor's Hommes et dieux: études d'histoire et de la littérature (1867).

Taine's Histoire dela littérature anglaise (1863-1864) is the source to which Henrich refers more times. He alludes or quotes from it on five occasions when dealing with Surrey (Henrich, 1881: 33), Lily (34), Ben Jonson (64), and Shakespeare's Macbeth (106-107) and A Midsummer Night's Dream (114-117). However, Henrich's main source is Craik's A Manual of English Literature (1862). In his view, Craik adopts the "clearest" and "most appropriate" method. He even admits that he extracted a good deal of information from Craik's work and decided to present the authors in the same order as the Scottish critic had done (Henrich, 1881: 28). An analysis of Craik's and Henrich's indexes reveals that he indeed considered Craik's organization although several modifications were introduced. Since the Spanish author did not conceive his Ensayo as such a long and comprehensive work as A Manual of English Literature, some writers were omitted and certain sections were considerably abridged. On the contrary, Henrich expanded the section devoted to Shakespeare, in which he made use of other sources. He mentions the editions of Shakespeare's works published by Rowe and Malone (Henrich, 1881: 71) and quotes from Guizot's introduction to CEuvres complètes de Shakspeare (107-109) and Staunton's The Works of Shakespeare (72-73), which he considers the best and most complete edition. In addition, he includes a long quotation from Goethe's Wilhelm Meisters Lehrjare translated into Spanish in the analysis of Hamlet (86-90) and passages from A. W. Schlegel's lectures, in which the German critic discusses Romeo and Juliet (9395), Othello (98-99), King Lear (102-103), and The Merchant of Venice (112-114). However, Schlegel's presence is not limited to these quotations on Shakespeare's plays. Henrich adopts Schlegel's conception of Classical and Romantic literature, which explains why he considers that Shakespeare and Milton were romantic writers (141). Flitter (2006: 3) has argued that Schlegel's Romantic historicism dominated the Spanish literary theory and criticism of the Romantic period, but Henrich's Ensayo reveals that his principles were still influential in the last decades of the nineteenth century.

Henrich also cites other literary histories such as Warton's History of English Poetry (Henrich, 1881: 27) and Hallam's Introduction to the Literature of Europe in the Fifteenth, Sixteenth, and Seventeenth Centuries (121). It should be noted, however, that he may not have consulted Warton's work and may have quoted it indirectly from Craik (1862). For instance, Henrich presumably quotes from Warton when he says:

Warton, en su Historia de la poesía inglesa dice: "El cronista que nos habla de este hecho, considera la traducción que encargó a Lydgate el abate Whethamstede, no como una obra literaria, sino como un trabajo manual, pues, dice, el abate pagó por la traducción, copias e iluminaciones, cien chelines" (Henrich, 1881: 27). 
Nonetheless, Craik reproduces this very same passage from Warton's work:

\footnotetext{
"The chronicler who records a part of this anecdote," observes Warton, "seems to consider Lydgate's translation as a matter of mere manual mechanism; for he adds, that Whethamstede paid for the translation, the writing, and illuminations, one hundred shillings" (Craik, 1862: 175-176).
}

Similarly, Henrich may not have consulted Ritson's Bibliographia Poetica. The information he extracts from this work when discussing fifteenth-century poetry (1881: 26-27) also appears in Craik (1862: 175).

Finally, Henrich cites Saint-Victor's Hommes et dieux: études d'histoire et de la littérature when he analyzes Swift's Gulliver's Travels, and Macaulay's essays when he deals with Bunyan and Byron. Two Spanish translations of Macaulay's essays had appeared under the titles Estudios literarios and Estudios críticos in 1879 and 1880, respectively. Nevertheless, since Henrich does not quote from those translations, he must have known the English originals or the French translations of Macaulay's essays published by Guizot.

\section{AN OVERVIEW OF THE RECEPTION OF ENGLISH LITERATURE IN SPAIN BY 1881}

Two factors determined the reception of English literature in Spain in the eighteenth and nineteenth centuries: the delay in the arrival of foreign literary and philosophical trends, and the mediation of France in the introduction of such trends. From a cultural perspective, Spain became considerably isolated as a result of the control exerted by the harsh state and inquisitorial censorship that was established in the sixteenth century and operated until the first decades of the nineteenth. Censorship succeeded in hindering the introduction and circulation of foreign books, but it frequently acted in an anachronistic and arbitrary way. For instance, Shakespeare's Othello, which premiered in Madrid in 1802, was banned by the Archbishop of Valencia as late as in 1829 (Carbonero y Sol, 2001: 495). It should be noted that the text in which the 1802 stage representation was based was not Shakespeare's original but Jean-François Ducis' Neoclassical French adaptation. This is not an exceptional case. Spanish translations of English works were usually based on French translations or adaptations of the English originals and the knowledge that the Spaniards had of English authors used to be mediated by French criticism. As we will see, all these aspects had an effect on

4 Detailed and accurate information on Shakespeare's representations in Spain can be found in the SHAKREP database created by the members of the project "Shakespeare en España en el marco de su recepción europea" from the University of Murcia. They also elaborated the SH ES TRA database, which contains information regarding the Spanish translations of Shakespeare's works. 
the chronology of the reception of English literature in Spain 5 .

The first timid approaches to English literature did not take place until the last decades of the eighteenth century. Before that time, the presence of English letters in the country had been merely incidental. The most significant traces of that presence were the Spanish translations of John Gower's Confessio Amantis in the mid-fifteenth century and Philip Sidney's Defence of Poetry in the seventeenth, but both translations remained in manuscript form. This situation changed in the late eighteenth century when certain English poets were first introduced in Spain. Spanish men of letters felt attracted by the philosophic and reflective tone of Pope and Thomson, and the originality of Young and Ossian (Alberich, 1994: 58; Lafarga, 2004: 287). Milton's Paradise Lost also aroused some interest. Pegenaute (1999: 321,325) remarks that Milton did not exert a genuine influence on Spanish authors, especially if compared with the influence of Pope, Young and Thomson in Spanish pre-Romantic poetry, but there were several attempts to translate Paradise Lost in the second half of the eighteenth century, including a translation of Canto I by Gaspar Melchor de Jovellanos in 1777. The first complete translations of Paradise Lost were published by Juan de Escoiquiz in 1812 and Benito Ramón de Hermida in 1814.

English eighteenth-century novelists also entered the Spanish literary market in this early phase of the reception. Spanish translations of Henry Fielding's Tom Jones and Amelia, Samuel Johnson's Rasselas, and Jonathan Swift's Gulliver's Travels were published in the 1790s ${ }^{6}$. However, the most popular English novelist in Spain at that time was Samuel Richardson. A Spanish translation of Pamela appeared between 1794 and 1795, and was soon followed by a translation of Clarissa published between 1794 and 1796, and one of The History of Sir Charles Grandison in 1798 (Pajares Infante, 1994). Since most of these translations were based on French renditions, Deacon (1998: 136137) indicates that the texts that the Spanish readership could access in their mother tongue had undergone a double process of manipulation. First, French translators did not simply translate the novels into their language, but felt free to adapt or suppress certain passages -mostly for moralistic purposes. Second, Spanish translators themselves also introduced their own modifications so as to expurgate them by removing all the elements that could be considered suspicious by the censors. As a result, those translated novels differed significantly from the English originals.

This early canon of English literature in Spain would not include Shakespeare.

5 The only panoramic account of the reception of English literature in Spain is Alberich (1994). There are studies on the reception of particular authors and periods, but a thorough analysis of the evolution of that reception from its origins to the present day has not been published yet.

6 For a detailed relation of the English novels that were translated into Spanish in the eighteenth and nineteenth centuries, see Pajares Infante (2006). 
Although there were several stage representations of his plays and Hamlet was translated into Spanish by Leandro Fernández de Moratín in 1798, Shakespeare was not truly known and appreciated until a later date. On this respect, the influence of France can be also noticed. French Neoclassical critics, who had condemned Shakespeare for his disregard of Classical rules, were highly influential in the eighteenth and part of the nineteenth centuries. Furthermore, Alberich (1994: 57) observes that the first approach to English literature and the selection of English authors that were introduced in Spain in the late eighteenth century -a selection that contemporary readers may consider weird- was also determined by the French taste.

France played a significant role in the reception of English literature in the Romantic period as well. As in France, Lord Byron and Walter Scott became the most celebrated English Romantic writers in Spain. In the case of Byron, his reception was complex and changeful. Some of his early readers considered him a novelist because a good number of the Spanish translations of his poems that appeared from the late 1820s were prose renditions based on French adaptations. Flitter (2004) traces the evolution of his reputation in Spain and concludes that he was first associated with the sublime aesthetics in the 1820s, and then condemned as a subversive figure by the Spanish conservative critics in the 1830s and 1840s. However, Byron became crucial in the development of Spanish Romanticism and, as Shaw (1988: 50-51, 59) and Cardwell (2004: 146,161) observe, he became the voice of the liberal trend of Spanish Romanticism and contributed to the liberation of Spanish literature from its prevailing traditionalist outlook. On the other hand, Walter Scott became a central literary figure for those who argued for a historicist conception of Romanticism. He became extremely popular and Spanish translations of his novels proliferated from 1825 onwards. In addition, Scott played a fundamental role in the development of the historical novel in Spain (Pegenaute, 2004: 342; Flitter, 2006: 45-46; García González and Toda, 2014: 55).

Shakespeare's presence in Spain is more visible during the Romantic period. He was frequently mentioned and praised in the critical writings that appeared in the Spanish press of the time, but the knowledge that the Spaniards had of his production was still limited (Alberich, 1994: 63). In addition, his reputation went through several upheavals. For instance, the 1838 stage representation of Macbeth, which was based on the faithful translation by José García de Villalta, was a complete failure (Calvo, 2002). The number of translations and representations of Shakespeare's plays gradually increased in the following decades, especially in the 1870s and 1880s. Palau (1969: 149-150) records ten different collected editions of Shakespeare's works in Spanish published between 1872 and 1886. At that time, numerous translations of his plays were edited separately as well (Palau, 1969: 155-167). Moreover, Gregor (2010: 63) points out that the repertoire of Shakespeare's plays was gradually broadened in the late nineteenth century due to 
the above-mentioned translations and the representation of plays that had never been staged before in that country ${ }^{7}$.

Therefore, the publication of Ensayo sobre la literatura inglesa took place during the major phase of the reception of Shakespeare in Spain in the nineteenth century. However, Shakespeare was not the only English author that attracted the attention of Spanish readers at that moment. The increasing number of Spanish translations of English works that were published in the last decades of the nineteenth century reveals that the knowledge and interest in English literature was greater than ever. For instance, this is the time when Charles Dickens became widely known in Spain. The first translations of his novels had been published in the 1840s, but it is from 1870 onwards when most of his narrative production was translated. As Galván and Vita indicate (2013: 170, 173), by the end of the nineteenth century, most of Dickens's major novels were available in Spanish translation and were published either in book form or in periodical publications. Nevertheless, many of these translations were still based on French renditions.

Besides Dickens, other Victorian authors were introduced in Spain at that time. This is the case of the novelist William Thackeray, the poet Alfred Tennyson, and nonliterary authors such as Charles Darwin and Thomas B. Macaulay (Santoyo, 2009: 581). In addition, there was an increasing interest in English authors that had been already known for some decades. Although Milton had been disregarded by Spanish Romantics, his reputation recovered in the last decades of the nineteenth century (Peers, 1926: 169; Pegenaute, 1999: 231). New translations of Paradise Lost appeared and Escoiquiz's rendition of 1812 was edited again (Palau, 1956: 267-268). Scott and Byron were still popular in Spain and their works were recurrently translated and edited until the end of the century. Similarly, the popularity of Robinson Crusoe had not diminished and numerous translations and adaptations of Defoe's novel were published throughout the whole century (Pajares Infante, 2006: 214-217).

\section{ENSAYO SOBRE LA LITERATURA INGLESA AND THE ENGLISH CANON}

According to the situation of the reception of English literature in Spain by the time of the publication of Ensayo sobre la literatura inglesa, a priori the selection of authors carried out by Henrich would not challenge the expectations of contemporary Spanish readers because he deals with those writers who arouse some interest in Spain at that time. Henrich places Shakespeare at the centre of the English canon and devotes almost

7 For example, there was an Italian representation of The Merchant of Venice in 1868 and a French one of A Midsummer Night's Dream in 1870. Furthermore, Antony and Cleopatra was first adapted to the Spanish stage in 1890, King Lear in 1893 and The Taming of the Shrew in 1894 (SHAKREP). 
a fifth part of his Ensayo to him (1881: 71-117). Besides providing a detailed biography and a chronology of his works, he analyzes seven of his plays: Hamlet, Romeo and Juliet, Othello, King Lear, Macbeth, The Merchant of Venice, and A Midsummer Night's Dream. He disagrees with Taine, who had placed Ben Jonson and Shakespeare at the same level, and favours the genius and originality of the Bard of Avon (1881: 64-65). On the whole, he shows a preference for what he considers the Romantic school and praises Milton and Byron enthusiastically too. The former is considered a great genius (141) and the latter the greatest modern English poet (242). He also includes those novelists that had been introduced in Spain in the nineteenth century, that is, Scott, Dickens, and Thackeray. Although the focus is on literary authors, he even mentions some prestigious nineteenth-century scientists, historians, economists and critics, such as Darwin, J. S. Mill, Carlyle, or Macaulay. As a result, one might rush into concluding that the canon presented by Henrich is in consonance with the stage of the reception of English literature in the late nineteenth century. However, there are some absences and presences that require further consideration.

Henrich ignores or pays little attention to the eighteenth-century poets Thomson, Young, and Ossian. Young and Thomson are just listed in a long enumeration of minor poets who did not stand out for their originality or style (Henrich, 1881: 189) and Ossian is not even mentioned. Given the nature of the work and the place that those authors occupied in the English canon from the nineteenth century onwards, those absences would not be noteworthy. In fact, Craik and Taine do not pay much attention to them either. Nevertheless, Henrich's disregard for those authors is significant if we consider the evolution of the reception of English literature in Spain and the popularity they had enjoyed before. For Glendinning (1968: 49), Thomson and Young -together with Pope- were the most influential English poets during the first stage of that reception. Arce (1981: 66-67) also highlights the presence of Young and considers him the best known and most quoted English poet in the late eighteenth century. In fact, some of Young's poems were translated into Spanish ${ }^{8}$, but the contribution of those translations to the knowledge of Young in Spain has been judged as "devastatingly poor" (López García, 1991: 160-161). However, the fact that several translations were published from the 1780s to the 1830s indicates that there was a constant interest in Young's poetry in Spanish pre-Romanticism and Romanticism. The popularity of Ossian's poems also extended over that period and did not diminish when the Spaniards finally discovered

8 The most important translation of Young's poems into Spanish was Juan de Escoiquiz's Obras selectas de Eduardo Young, expurgadas de todo error, which was first published in 1789-1790 and reedited in 1798 and 1804. Before that, in 1785, Cristóbal Cladera had published his version of The Final Judgement, which was edited again in 1834. In the nineteenth century, another three translations were produced: El sabio de la soledad o Meditaciones religiosas by Antonio Schawer (published in 1802 or 1807 and reedited in 1819); Lamento nocturno, o Meditaciones de Young presumably by Francisco Razola (published in 1822 and reprinted in 1826); Obras impresas del Dr. Eduardo Young (1833), which is an apocryphal collection of moral sayings. López García (1991) briefly analyzes these Spanish renditions and comments on certain French and Italian translations that eighteenth-century Spaniards may have also read. 
that they were Macpherson's forgery (Alberich, 1994: 61-62). In spite of the scarcity of translations ${ }^{9}$, Ossian's poems and the sublime aesthetics to which they were ascribed became significantly influential in the Spanish literary and critical production of the first decades of the nineteenth century. Even though Ossian was not a passing trend and Montiel (1974: 37) insists on the presence of ossianic echoes in the second half of the nineteenth century, his popularity had decreased considerably by 1881 .

On the contrary, Henrich includes authors who were still practically unknown in Spain, but were to play a significant role in the twentieth century. This is the case of Wordsworth and Coleridge, whose presence in Spain in the nineteenth century can be hardly traced. Only Coleridge's "The Rime of the Ancient Mariner" was translated into Spanish before 1900. A translation of this poem entitled El antiguo marino by B. Archer was published around 1890. In addition, there were some spare references to these authors in certain Spanish critical writings, including Alcalá Galiano's preface to El moro expósito (1834: xxiv, xxvii) and the above-mentioned Historia de la literatura española, francesa, inglesa e italiana en el siglo XVIII (1845: 399-400). It should be noted that Alcalá Galiano fled to England in 1823 after the reestablishment of absolutism by Ferdinand VII. As in the case of other liberal exiles such as José María Blanco White and José Joaquín de Mora, his stay in London allowed him to become acquainted with contemporary Romantic poetry. Perojo Arronte (2007: 133) indicates that, although these exiled authors received Coleridge's poetry and poetics warmly, the major phase of his reception took place in the twentieth century. Wordsworth's reception underwent a similar evolution. In fact, the reception of both poets is closely linked and someSpanish authors came to know Coleridge's writings via Wordsworth's (Perojo Arronte, 2007: 137, 163). Henrich, who deals with them in a section entitled “Escritores de principios del siglo XIX" (1881: 205-211), considers them -together with Southey- the leaders of the new school (206). He does not specify if that school is called Romanticism, but he must have meant so because in the preceding sentence he mentions the re-importation of Romanticism from Germany. At this point, he distances from English literary historiography and criticism, and from Craik (1862) in particular ${ }^{10}$. Craik (1862: 459) does not assign the label "Romantic poets" to Wordsworth, Coleridge, and Southey,

9 The first translation was José Alonso Ortiz's Obras de Ossian, poeta del siglo tercero en las montañas de Escocia, a volume published in 1788 that contained both prose and verse renditions of the poems "Carthom" and "Lathmon". Later on, Fingal y Temora, poemas épicos de Osián, antiguo poeta céltico by Pedro Montegón appeared in 1800.

10 English nineteenth-century critics did not systematically apply the term "Romantic" to the so called English Romantic poets until a late date. In 1882, Mrs. Oliphant still avoids its use in Literary History of England and refers to different groups or schools, such as the Lake School or the Satanic School, when discussing the poetry of the first decades of the nineteenth century (Wellek, 1971: 149-150). Even twentyfirst-century critics like Cochran (2009) are sceptical about the use of the term romantic; he claims that the idea of an "English Romantic school" was the invention of Taine and was not convincingly used in English criticism until the end of the nineteenth century (xvii-xviii). 
and refers to them as the "Lake school of poets," a denomination that also appears in Henrich's work (1881: 207). As a matter of fact, the section "Escritores de principios del siglo XIX" is based on Craik's Manual. Henrich extracts the information on Wordsworth and Coleridge from it, but he does so in an inaccurate and arbitrary way. For example, he reproduces Craik's criticism on Wordsworth's definition of poetry (Craik, 1862: 459461; Henrich, 1881: 207-208), but he disregards some of Wordsworth's and Coleridge's most outstanding productions. He also seems to ignore the fact that the Lyrical Ballads were composed by both Wordsworth and Coleridge, even though it is explained by Craik (1862: 474). Consequently, Henrich neither possessed a deep knowledge of their poetry, nor understood the actual importance they had in the evolution of the Romantic movement. However, he deemed them worthy of being included in his work.

\section{CONCLUSION}

An analysis of Henrich's Ensayo sobre la literatura inglesa reveals its strong dependence on its foreign sources, especially Craik's A Manual of English Literature and Taine's Histoire de la littérature anglaise. To a considerable extent, these sources determined the English literary canon he presented. His selection of authors differs significantly from the canon that had prevailed during the early stages of the reception of English writers in Spain and offers a wider repertoire which is more in tune with the new phase of this reception in the three last decades of the nineteenth century. Ensayo sobre la literatura inglesa was published at a time of growing knowledge and interest in English literature, when the Spanish translations of English works proliferated and English writers became better appreciated. Henrich's work contributed to the formation of a new English canon that was taking place in Spain at that moment in three different ways. First, he disregards authors who, in spite of their popularity in the pre-Romantic and Romantic periods, had been pushed into the background in the following decades. Second, he reaffirms the central position occupied by some of the by-then established canonical figures such as Shakespeare, Milton or Byron, and pays attention to the Victorian writers who were introduced in Spain at that time. Third, he anticipates the presence of authors like Wordsworth or Coleridge, who had not been known in Spain yet, but were to become influential in the twentieth century. Consequently, despite the inaccuracies and limitations of Henrich's work, it should be considered in the study of the reception of English literature in the second half of the nineteenth century, a period in which many aspects of the actual presence and impact of English writers on the Spanish literary panorama still remain obscure. 


\section{BiBLIOGRAPHY}

Alberich, J. M. (1994): "La difusión de la literatura inglesa en España”, Minervae Baeticae. Boletín de la Real Academia Sevillana de Buenas Letras, 22: 49-71.

Alcalá Galiano, A. (1834): "Prólogo", in Á. Saavedra (1834) El moro expósito, París, Librería Hispanoamericana: ix-xxi.

Alcalá Galiano, A. (1845): Historia de la literatura española, francesa, inglesa e italiana en el siglo XVIII, Madrid, Imprenta de la Sociedad Literaria y Tipográfica.

Arce, J. (1981): La poesía del siglo ilustrado, Madrid, Alhambra.

Botrel, J. F. (1993): Libros, prensa y lectura en la España del siglo XIX, Madrid, Fundación Germán Sánchez Ruipérez.

Cabana i Vancells, F. (2002): Manuel Girona: Semblança i antologia de textos, Barcelona, Pòrtic.

Calvo, C. (2002): “Románticos españoles y tragedia inglesa: el fracaso del Macbeth de José García de Villalta”, in F. Lafarga, C. Palacios y A. Saura (eds.) (2002) Neoclásicos y románticos ante la traducción, Murcia, Universidad de Murcia: 59-72.

Carbonero y Sol, L. (2001): Índice de los libros prohibidos por el Santo Oficio de la Inquisición española, Valladolid, Maxtor.

Cardwell, R. A. (2004): “'El Lord Sublime': Byron's Legacy in Spain”, in R. A. Cardwell (ed.) (2004) The Reception of Byron in Europe. Volume 1: Southern Europe, France and Romania, London, Thoemmes Continuum: 144-163.

Chateaubriand, F. R. (1836): Essai sur la littérature anglaise, Paris, Furne et Charles Gosselin.

Chateaubriand, F. R. (1857): Ensayo sobre la literatura inglesa, Madrid, Imprenta de Gaspar y Roig.

Cochran, P. (2009): "Romanticism" -and Byron, Newcastle upon Tyne, Cambridge Scholars.

Craik, G. L. (1862): A Manual of English Literature, London, Charles Griffin and Company.

Deacon, P. (1998): "Novela inglesa en la España del siglo XVIII: Fortuna y adversidades", in F. García Lara (ed.) (1998) I Congreso Internacional sobre novela del siglo XVIII, Almería, Universidad de Almería: 125-139.

Flitter, D. (2004): "'The Immortal Byron' in Spain: Radical and Poet of the Sublime”, in R. A. Cardwell (ed.) (2004) The Reception of Byron in Europe. Volume 1: Southern Europe, France and Romania, London, Thoemmes Continuum: 129-143.

Flitter, D. (2006): Spanish Romantic Literary Theory and Criticism, Cambridge, Cambridge University Press.

Galván, F. and Vita, P. (2013): “The Spanish Dickens: Under Cervantes's Inevitable Shadow", in M. Hollington (ed.) (2013) The Reception of Charles Dickens in Europe, London, Bloomsbury: 169-181.

García González, J. E. and Toda, F. (2014): “The Reception of Sir Walter Scott in Spain", in M. Pittock (ed.) (2014) The Reception of Sir Walter Scott in Europe, London, Bloomsbury: 45-63.

Glendinning, N. (1968): Influencia de la literatura inglesa en España en el siglo XVIII, Oviedo, Universidad de Oviedo. 
Goethe, J. W. (1795-1796): Wilhelm Meisters Lehrjahre, 4 vols., Berlin, J. F. Unger.

Gregor, K. (2010): Shakespeare in the Spanish Theatre: 1772 to the Present, London, Continuum.

Guizot, F. (1821): CEuvres complètes de Shakspeare, Paris, Chez Ladvocat.

Hallam, H. (1837-1839): Introduction to the Literature of Europe in the Fifteenth, Sixteenth, and Seventeenth Centuries, 4 vols., London, Murray.

Henrich y Girona, J. (1881): Ensayo sobre la literatura inglesa, Barcelona, Imprenta de los sucesores de Ramírez y Cía.

Instituto provincial de Huelva (1886): Memoria del instituto provincial de Huelva perteneciente al año académico 1884-1885, Huelva, Imprenta de la viuda e hijos de Muñoz.

Lafarga, F. (2004): “El siglo XVIII, de la Ilustración al Romanticismo”, in F. Lafarga and L. Pegenaute (eds.) (2004) Historia de la traducción en España. Salamanca, Editorial de Ambos Mundos: 209-319.

Llanas, M. (2004): L'edició a Catalunya: el segle XIX, Barcelona, Gremi d'Editors de Catalunya.

López García, D. (1991): “La huella de Young en España”, in D. López García (ed.) (1991) Sobre la imposibilidad de la traducción, Cuenca, Universidad de Castilla-La Mancha: 159-177.

Macaulay, T. B. (1843): Critical and Historical Essays: Contributed to the Edinburgh Review, 3 vols., London, Longman.

Macaulay, T. B. (1879): Estudios literarios, Madrid, Imprenta Central a cargo de Víctor Saiz.

Macaulay, T. B. (1880): Estudios críticos, Madrid, Imprenta Central a cargo de Víctor Saiz.

Mac-Veigh, H. (1857): The British Class Book o Lecciones de literatura inglesa, Madrid, Imprenta de Don Alejandro Gómez Fuentenebro.

Malone, E. (1790): The Plays and Poems of William Shakespeare, 10 vols., London, Rivington and Sons.

Montiel, I. (1974): Ossián en España, Barcelona, Editorial Planeta.

Pajares Infante, E. (1994): "Samuel Richardson's Presence and Absence in Spain", Revista Alicantina de Estudios Ingleses, 7: 159-170.

Pajares Infante, E. (2006): La novela inglesa en traducción al español durante los siglos XVIII y XIX: aproximación bibliográfica, Barcelona, Promociones y Publicaciones Universitarias.

Palau, A. (1956): Manual del librero hispanoamericano, tomo IX: Mena - Molloy, Barcelona, Palau.

Palau, A. (1969): Manual del librero hispanoamericano, tomo XXI: Senén - Soms, Barcelona, Palau.

Peers, E. A. (1926): “Milton in Spain”, Studies in Philology, 23: 169-183.

Pegenaute, L. (1999): “La recepción de Milton en la España Ilustrada: Visiones de El Paraíso perdido", in F. Lafarga (ed.) (1999) La traducción en España (1750-1830). Lengua, literatura, cultura, Lleida, Universidad de Lleida: 321-334.

Pegenaute, L. (2004): “La época romántica”, in F. Lafarga and L. Pegenaute (eds.) (2004) 
Historia de la traducción en España, Salamanca, Editorial de Ambos Mundos: 321-396.

Perojo Arronte, M. E. (2007): "Imaginative Romanticism and the Search for a Transcendental Art: Coleridge's Poetry and Poetics in Nineteenth-Century Spain", in E. Zuccato and E. S. Shaffer (eds.) (2007) The Reception of S. T. Coleridge in Europe, London, Continuum: 133-166.

Ritson, J. (1802): Bibliographia Poetica, London, Roworth.

Rowe, N. (1709): The Works of Mr. William Shakespear, 6 vols., London, Jacob Tonson.

Saint-Victor, P. (1867): Hommes et dieux: études d'histoire et de la littérature, Paris, Michel Lévy.

Santoyo, J. C. (2009): "Inglesa de Gran Bretaña, Literatura", in F. Lafarga and L. Pegenaute (eds.) (2009) Diccionario histórico de la traducción en España, Madrid, Editorial Gredos: 577-587.

Schlegel, A. W. (1809-1811): Vorlesungen über dramatische Kunst und Literatur, Heidelberg, Mohr and Zimmer.

SHAKREP Representaciones de Shakespeare en España, online database https://www. um.es/shakespeare/representaciones/ (accessed 18th March 2014).

SH ES TRA Shakespeare en España en traducción, online database, https://www.um.es/ shakespeare/shestra/ (accessed 18th March 2014).

Shaw, D. L. (1988): “Byron and Spain”, Renaissance and Modern Studies, 32.1: 45-59.

Staunton, H. (1858-1860): The Works of Shakespeare, 3 vols., London, Routledge.

Taine, H. (1863-1864): Histoire de la littérature anglaise, 5 vols., Paris, Librairie de L. Hachette et Cie.

Warton, T. (1774-1881): The History of English Poetry, 3 vols., London, Dodsley.

Wellek, R. (1971): “The Concept of Romanticism in Literary History ", in S. G. Nichols (ed.) (1971) Concepts of Criticism, New Haven, Yale University Press: 128-198. 